\title{
Methodological Aspects of Decision Support System for the Location of Renewable Energy Sources
}

\author{
Jarosław Wątróbski \\ West Pomeranian University of \\ Technology in Szczecin, \\ Żołnierska 49, 71-210 Szczecin, \\ Poland \\ Email: jwatrobski@wi.zut.edu.pl
}

\author{
Paweł Ziemba \\ The Jacob of Paradyż University of \\ Applied Sciences in Gorzów \\ Wielkopolski, Chopina 52, 66-400 \\ Gorzów Wielkopolski, Poland \\ Email: pziemba@pwsz.pl
}

\author{
Waldemar Wolski \\ University of Szczecin, \\ Mickiewicza 64, 71-101 Szczecin, \\ Poland \\ Email: \\ wwolski@uoo.univ.szczecin.pl
}

\begin{abstract}
The aim of this article is to present the methodological framework for Decision Support System for the process of selecting the location of renewable energy sources. For this purpose, the paper presents the methodology and MCDA methods sequentially structuralizing and modeling the decision space and exploiting the developed model. The detailed area of research and verification of proposed approach are related to the problem of offshore wind farm localization. Proposed framework defines input information together with methodological background required for decision support processes.
\end{abstract}

\section{INTRODUCTION}

$\mathrm{I}$ $\mathrm{n}$ recent years, there has been increasing interest in renewable energy sources (RES). The conditions for such a situation are related to the development of new technologies that look for ways of making the national economies of many countries more independent from conventional energy sources. Additionally, the continuing decline of natural energy resources, while their prices increase in the global market, has forced changes in macro and micro strategies to find new sources of energy. Renewable energy sources can be used almost anywhere in the world. The main problem is establishing the correct economical, technological, environmental and social justifications for the location and infrastructure construction using new technologies and resources. In terms of this study, the above issues were narrowed by focusing on the use of offshore wind farms. Decision related to selection of renewable energy sources should be taken carefully due to high impact on environment and community. Big number of factors and preferences create area for the use of Decision Support Systems [13]. Due to the complex set of factors, determining the multi-criteria profitability of this class of investments in wind energy for further study the MCDA methods were used as a methodological basement. This approach is also justified by the analysis of previous studies related to selecting and evaluating renewable energy installations.

\section{RENEWABLE ENERGY SOURCES}

According to the classification of the World Energy Council, wind energy is one of the various types of renewable energy sources [1]. This type of energy is used to produce electricity, utilizing wind farms composed of devices using wind turbines to convert wind energy into mechanical energy, which is then converted into electrical energy [3]. The effective operation of a wind farm is crucially influenced by the choice of location. This choice determines the efficiency of its operation and also has an impact on the costs, the benefits, and the environment. For obvious reasons, potential areas for the implementation of this type of investment must be assessed in terms of numerous factors: wind, water depth, and possible conflicts or formal legal exclusions (for example, if the potential area is located in a protected area [4]). In addition, there is a complex set of factors determining the success of this type of investment. Detailed analyses include determining the impact on the marine environment of the investment area and existing users of those areas. The fact that offshore wind farms generate some noise and have an impact on the landscape, which in turn affects the level of acceptance from local communities, must also be considered. That is why it is important to maintain an adequate distance from areas where there are marine mammals, fish species particularly sensitive to noise, birds, marine space, and fishing areas. Improperly located farms can be a source of negative environmental and social impacts. Another extremely important consideration is therefore the appropriate selection of criteria, which determines the accuracy of the entire decision-making process. The multitude of often conflicting criteria makes it methodologically formulated as a multi-criteria decision problem. Among the many available methods of research, the AHP method and Promethee II were chosen for this study; therefore, the article presents the concept of multicriteria model for a decision support system for choosing an investment location.

Review of the existing literature indicates the possibility of using multi-criteria decision methods for problems of selection for different types of economic activities. For 
example, Forte [16], in the assessment of land management options, used the method of REGIME, NAIADE, AHP and FLAG. In [20], the region in the context of the use of various installations of renewable energy sources using the AHP method was assessed. Similar problems were also solved by Burton and Hubacek [14], who used the method of MACBETH and assessed the potential locations of such facilities. Eleftheriadou and others [19] used the PROMETHEE II method to evaluate the different variants in the foundation of wind turbines. Such a problem is presented also in the work of Cavallaro and Ciraolo [15], where the authors used the NAIADE method. This method was also proposed in the work of Gamboa and Munda [17] to assess the potential for wind farms in Spain. In contrast, the work in [19] was devoted to the evaluation of alternatives that consider different possibilities for the deployment of wind farms in one of the provinces in China, with the help of the AHP method. The work of Georgopoulou [18] is also relevant, as that research integrated different types of RES in Greece using the ELECTRE III method. The synthesis of research relating to the use of MCDA methods in problems of RES locations are given in Table 1.
III. THE USE OF MULTI-CRITERIA DECISION SUPPORT METHODS IN CHOSING THE LOCATION OF AN OFFSHORE WIND FARM

The procedure presented in this paper is in accordance with the guidelines contained in [8] and includes five successive stages:

- defining a set of decision variants,

- structuring the decision problem,

- setting priority vectors using the AHP method,

- exploitation of model and ranking of the decision variants using the Promethee II method,

- interpretation of the model with Plane Gaia and a sensitivity analysis of the set of decisions.

The first step in obtaining solutions is to define a set of decision variants for the problem of choosing the location of offshore wind farms in the Baltic Sea. Based on the map developed by the Maritime Institute in Gdansk [5] [6], including a list of potential sites for the location of offshore wind farms, 6 areas were selected. On this basis, a 6-piece set of variants for decision-making was established: $\mathrm{W}=$ $\{\mathrm{W} 1, \mathrm{~W} 2, \mathrm{~W} 3, \mathrm{~W} 4, \mathrm{~W} 5, \mathrm{~W} 6\}$, where $\mathrm{Wn}$ is one of the locations on the Baltic Sea. The locations are shown in Figure 1.

TABLE I. RESEARCH RELATING TO THE USE OF MCDA METHODS IN PROBLEMS OF RES LOCATIONS

\begin{tabular}{|c|c|c|c|c|c|c|c|c|c|}
\hline \multirow{2}{*}{ No. } & \multirow{2}{*}{ Assessment } & \multirow{2}{*}{ Category } & \multicolumn{3}{|c|}{ Main criteria } & \multirow{2}{*}{ Method } & \multirow{2}{*}{$\begin{array}{c}\text { Number of } \\
\text { criteria }\end{array}$} & \multirow{2}{*}{$\begin{array}{c}\text { Type of } \\
\text { data }\end{array}$} & \multirow{2}{*}{ Ref. } \\
\hline & & & Spatial & Environmental & Economical & & & & \\
\hline 1 & Selecting site location & $\mathrm{TS}+\mathrm{SL}$ & $\mathrm{L}$ & SA & IC, MC & AHP & 9 & qualitive & [25] \\
\hline 2 & Selecting site location & SL & $\mathrm{L}$ & EI & $\mathrm{IC}, \mathrm{MC}, \mathrm{EC}$ & Macbeth & 8 & qualitive & [14] \\
\hline 3 & Selecting site location & SL & $\mathrm{L}$ & SA & $\mathrm{IC}$ & Promethee II & 7 & qualitive & [19] \\
\hline 4 & Selecting site location & SL & $\mathrm{U}, \mathrm{L}$ & SA & $\mathrm{IC}, \mathrm{MC}$ & Naiade & 9 & mixed & [15] \\
\hline 5 & Selecting site location & SL & $\mathrm{U}, \mathrm{L}, \mathrm{T}$ & $\mathrm{WN}$ & IC & Naiade & 10 & mixed & [17] \\
\hline 6 & Selecting site location & SL & $\mathrm{U}$ & SA & $\mathrm{IC}, \mathrm{MC}$ & AHP & 12 & mixed & [19] \\
\hline 7 & $\begin{array}{l}\text { Selecting of renewable energy } \\
\text { power plant technologies }\end{array}$ & TS & $\mathrm{L}$ & EI & $\mathrm{IC}, \mathrm{MC}$ & Fuzzy DEA & 7 & qualitive & [26] \\
\hline 8 & $\begin{array}{c}\text { Selection of suitable electricity } \\
\text { generation alternatives }\end{array}$ & TS & $\mathrm{U}, \mathrm{L}$ & WN & IC & Promethee & 5 & mixed & [27] \\
\hline 9 & $\begin{array}{l}\text { Selecting of renewable energy } \\
\text { power plant technologies }\end{array}$ & TS & $\mathrm{U}, \mathrm{L}$ & SA & $\mathrm{IC}, \mathrm{MC}$ & Electre III & 8 & quantative & [18] \\
\hline 10 & $\begin{array}{c}\text { Renewable energy sources } \\
\text { project selection }\end{array}$ & SL & $\mathrm{ED}, \mathrm{U}, \mathrm{L}$ & $\mathrm{WN}, \mathrm{SA}$ & $\mathrm{IC}, \mathrm{MC}$ & Electre & 8 & mixed & [28] \\
\hline 11 & $\begin{array}{l}\text { Derive wind farm land } \\
\text { suitability index and } \\
\text { classification }\end{array}$ & SL & $\mathrm{U}$ & WN & IC & AHP & 10 & mixed & [29] \\
\hline 12 & $\begin{array}{l}\text { Derive wind farm land } \\
\text { suitability index and } \\
\text { classification }\end{array}$ & SL & $\mathrm{L}$ & EI, SA & $\mathrm{IC}, \mathrm{MC}$ & Fuzzy AHP & 9 & mixed & [31] \\
\hline 13 & $\begin{array}{c}\text { Assessment of land } \\
\text { management options }\end{array}$ & TS & $\mathrm{U}, \mathrm{L}$ & WN & $\mathrm{IC}, \mathrm{MC}$ & AHP & 12 & mixed & [20] \\
\hline 14 & $\begin{array}{c}\text { Define energy indicators used } \\
\text { in the assessment of energy } \\
\text { systems which meet } \\
\text { sustainability criterion }\end{array}$ & TS & $\mathrm{L}$ & SA & IC, EC & $\begin{array}{l}\text { weighted } \\
\text { arithmetic } \\
\text { mean }\end{array}$ & 5 & quantative & [30] \\
\hline
\end{tabular}




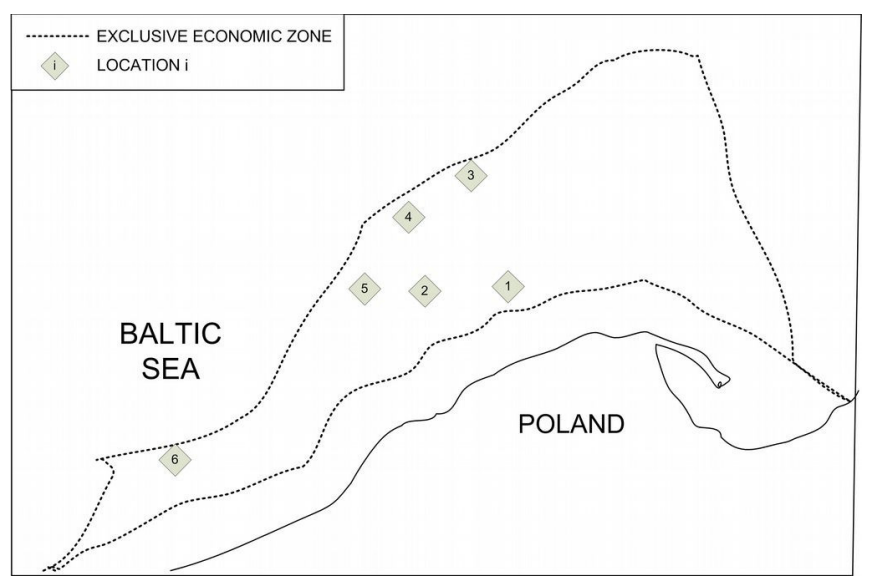

Fig 1. Map of potential locations

Selected locations have similar wind conditions, but vary in size, which determines the number of possible wind turbines that can be installed.

In the next step, the structure of the decision problem was identified. Analysis of work related to wind energy, including [2] [17] [3] [19] was used as a foundation to build a set of criteria: $K=\{K 1, K 2, K 3\}$, where: $K 1$ - spatial factors, K2 - economic factors, K3 - the social and environmental risks. As part of a set of criteria, three subsets were extracted: $\mathrm{K} 1=\{\mathrm{K} 11, \mathrm{~K} 12, \mathrm{~K} 13, \mathrm{~K} 14\}, \mathrm{K} 2=\{\mathrm{K} 21$, $\mathrm{K} 22, \mathrm{~K} 23\}, \mathrm{K} 3=\{\mathrm{K} 31, \mathrm{~K} 32, \mathrm{~K} 33\}$, where: $\mathrm{K} 11$ - the average depth of the basin [m] , K12 - the distance from the shoreline [km], K13 - distance to connection NEN (National Energy Network) [km], K14 - the type of seabed; K21 - the cost of the investment, K22 - payback time, K23 - annual energy production; K31 - conflict with fisheries, K32 - the risk of navigation safety, and K33 - the impact on protected areas. The detailed specifications are shown in Table 2. The values of the criteria for each decision variant were determined using the reference literature contained in Table 2 , and their resultant values are shown in Table 3.

Given the above results from individual investigations, the criteria were defined. Due to the fact that the different sets of criteria are related to different perspectives of looking at the same decision-making problem, it is difficult to clearly and objectively determine their weight. Consequently, it was assumed that the weight of each of the sets are mutually equal: $\mathrm{K} 1=\mathrm{K} 2=\mathrm{K} 3$. On the other hand, to determine the weights of the more specific criteria within each set, the AHP method was used [21]. This method was used because it is difficult to determine the absolute values of the weights of the individual criteria. However, the AHP method allows for the determination of the relative weights of criteria by

TABLE II. DetaILED SPECIFICATIONS OF EVALUATION CRITERIA

\begin{tabular}{|c|c|c|c|c|c|}
\hline \multicolumn{3}{|r|}{ Criteria } & \multirow[t]{2}{*}{$\begin{array}{r}\text { Type of } \\
\text { criterion }\end{array}$} & \multirow[t]{2}{*}{ Description of criterion } & \multirow[t]{2}{*}{$\begin{array}{l}\text { Reference } \\
\text { literature }\end{array}$} \\
\hline $\mathrm{K} 1$ & \multicolumn{2}{|r|}{ Spatial factors } & & & \\
\hline & K11 & Average depth of the basin $[\mathrm{m}]$ & cost & Was determined in each location on the basis of the available bathymetry data. & {$[5]$} \\
\hline & $\mathrm{K} 12$ & Distance from the shoreline $[\mathrm{km}]$ & cost & $\begin{array}{l}\text { Distance from the coast is measured in a straight line. The increase in the distance } \\
\text { from the edge causes a significant increase in the cost of building the farm } \\
\text { (transport equipment, longer build time). }\end{array}$ & {$[5]$} \\
\hline & K13 & $\begin{array}{l}\text { Distance from the NEN } \\
\text { connection }[\mathrm{km}]\end{array}$ & cost & Distance of each farm to the nearest NEN port. & [7] \\
\hline & K14 & Type of seabed & profit & $\begin{array}{l}\text { Quality rating of the seabed for marine construction: rocky bottom - the best, } \\
\text { grainy - very good, silty-sandy bottom - good, muddy - moderately good. }\end{array}$ & {$[6],[12]$} \\
\hline $\mathrm{K} 2$ & \multicolumn{2}{|r|}{ Economic factors } & & & \\
\hline & $\mathrm{K} 21$ & $\begin{array}{l}\text { The investment cost [million } \\
\text { PLN] }\end{array}$ & cost & Investment costs were estimated assuming a $7 \mathrm{MW}$ turbine power. & {$[7],[9]$} \\
\hline & K22 & Payback time [years] & $\operatorname{cost}$ & $\begin{array}{l}\text { The calculation of payback periods makes possible to obtain annual profit. This } \\
\text { value is determined using the unit price of electricity, the unit price of certificates } \\
\text { of origin, and operating costs. Based on the calculated profit for the year, as well } \\
\text { as taking into account the specified operating baskets payback time. }\end{array}$ & {$[9],[3]$} \\
\hline & K23 & $\begin{array}{l}\text { Annual energy production } \\
{[\mathrm{GWh}]}\end{array}$ & profit & $\begin{array}{l}\text { Annual energy production is based on information concerning the annual average } \\
\text { wind speed and wind turbine performance. }\end{array}$ & [7], [9], [1] \\
\hline $\mathrm{K} 3$ & \multicolumn{2}{|r|}{ Environmental and social risk } & & & \\
\hline & K31 & Conflict with fisheries & cost & $\begin{array}{l}\text { Conflict of interest with the marine fisheries sector was estimated at a } 9 \text { points } \\
\text { scale with } 9 \text { as the biggest conflict). }\end{array}$ & {$[6]$} \\
\hline & K32 & Threat to navigation safety & cost & $\begin{array}{l}\text { Based on the traffic map of water, determining how much influence it can have } \\
\text { on a location for sailing in terms of possible dangers of ship collisions with wind } \\
\text { farms. }\end{array}$ & {$[10]$} \\
\hline & K33 & Influence on the protected areas & $\operatorname{cost}$ & $\begin{array}{l}\text { The proximity of Natura } 2000 \text { protected areas of the potential offshore location. } \\
\text { Determines the possible impact of investment on the protected areas on a nine- } \\
\text { element scale, assuming that } 1 \text { means the least impact on protected areas, while } 9 \\
\text { is the biggest. }\end{array}$ & {$[11]$} \\
\hline
\end{tabular}


TABLE III. VALUES OF CRITERIA FOR DECISION VARIANTS

\begin{tabular}{|c|c|c|c|c|c|c|c|c|}
\hline \multicolumn{3}{|r|}{ Criteria } & \multicolumn{6}{|c|}{ Variants } \\
\hline \multirow[t]{5}{*}{ K1 } & \multicolumn{2}{|r|}{ Spatial factors } & W1 & W2 & W3 & W4 & W5 & W6 \\
\hline & K11 & Average depth of the basin $[\mathrm{m}]$ & 40 & 31 & 29 & 62 & 51 & 35 \\
\hline & K12 & Distance from the shoreline $[\mathrm{km}]$ & 34,7 & 45,6 & 86,3 & 77,1 & 63,1 & 44,9 \\
\hline & K13 & Distance from the NEN connection $[\mathrm{km}]$ & 31 & 45 & 82 & 79 & 61 & 41 \\
\hline & K14 & Type of seabed & very good & good & very good/good & moderately good & very good & good \\
\hline \multirow[t]{4}{*}{ K2 } & \multicolumn{2}{|r|}{ Economic factors } & & & & & & \\
\hline & $\mathrm{K} 21$ & The investment cost [million PLN] & 9040 & 9023 & 11231 & 10602 & 7870 & 7324 \\
\hline & K22 & Payback time [years] & 9 & 10 & 11 & 15 & 14 & 12 \\
\hline & $\mathrm{K} 23$ & Annual energy production [GWh] & 2803 & 2432 & 3132 & 3415 & 2132 & 1897 \\
\hline \multirow[t]{4}{*}{$\mathrm{K} 3$} & \multicolumn{2}{|r|}{ Environmental and social risk } & & & & & & \\
\hline & K31 & Conflict with fisheries & 8 & 5 & 9 & 4 & 5 & 6 \\
\hline & K32 & Threat to navigation safety & 2 & 1 & 5 & 1 & 5 & 2 \\
\hline & K33 & Influence on the protected areas & 2 & 8 & 1 & 1 & 4 & 1 \\
\hline
\end{tabular}

mutually comparing their validity in a pairwise comparisons matrix, and then aggregating the results of these comparisons in the vector of preference. This is more effective for the decision-maker than determining the absolute weights [22], as one of the criteria for significance here is the point of reference in determining the validity of the other. The arrays of paired comparisons within the validity criteria sets of criteria $\mathrm{K} 1=\{\mathrm{K} 11, \mathrm{~K} 12, \mathrm{~K} 13, \mathrm{~K} 14\},\{\mathrm{K} 2=\mathrm{K} 21, \mathrm{~K} 22$, $\mathrm{K} 23\},\{\mathrm{K} 3=\mathrm{K} 31, \mathrm{~K} 32, \mathrm{~K} 33\}$ are contained in Tables 4, 5 and 6 .

TABLE IV. PAIRWISE COMPARISONS OF VALIDITY OF THE "SPATIAL FACTORS" CRITERIA

\begin{tabular}{|c|c|c|c|c|c|}
\hline $\mathbf{C R}=\mathbf{0 , 0 0 4}$ & $\mathbf{K 1 1}$ & $\mathbf{K 1 2}$ & $\mathbf{K 1 3}$ & $\mathbf{K 1 4}$ & Weights (K1) \\
\hline $\mathbf{K 1 1}$ & 1 & $1 / 2$ & $1 / 2$ & 2 & 0,189 \\
\hline $\mathbf{K 1 2}$ & 2 & 1 & 1 & 3 & 0,351 \\
\hline $\mathbf{K 1 3}$ & 2 & 1 & 1 & 3 & 0,351 \\
\hline $\mathbf{K 1 4}$ & $1 / 2$ & $1 / 3$ & $1 / 3$ & 1 & 0,109 \\
\hline
\end{tabular}

TABLE V. PairWise COMParisons of VAlidity of the "eCONOMiC FACTORS" CRITERIA

\begin{tabular}{|c|c|c|c|c|}
\hline $\mathbf{C R}=\mathbf{0 , 0 2 4}$ & $\mathbf{K 2 1}$ & $\mathbf{K 2 2}$ & $\mathbf{K 2 3}$ & Weights (K2) \\
\hline $\mathbf{K 2 1}$ & 1 & 3 & $1 / 2$ & 0,32 \\
\hline $\mathbf{K 2 2}$ & $1 / 3$ & 1 & $1 / 4$ & 0,122 \\
\hline $\mathbf{K 2 3}$ & 2 & 4 & 1 & 0,558 \\
\hline
\end{tabular}

TABLE VI. PAIRWISE COMPARISONS OF VALIDITY OF THE "SOCIOENVIRONMENTAL HAZARDS" CRITERIA

\begin{tabular}{|c|c|c|c|c|}
\hline $\mathbf{C R}=\mathbf{0 , 0 0 9}$ & $\mathbf{K 3 1}$ & $\mathbf{K 3 2}$ & $\mathbf{K 3 3}$ & Weights (K3) \\
\hline $\mathbf{K 3 1}$ & 1 & $1 / 2$ & 2 & 0,297 \\
\hline $\mathbf{K 3 2}$ & 2 & 1 & 3 & 0,54 \\
\hline $\mathbf{K 3 3}$ & $1 / 2$ & $1 / 3$ & 1 & 0,163 \\
\hline
\end{tabular}

Tables 4, 5, 6 also show a right-hand value in each eigenvector matrix. This vector contains the aggregate weight of each criterion.

Assuming different weights of the individual sets of criteria $(\mathrm{K} 1=\mathrm{K} 2=\mathrm{K} 3)$, the global weights of the criteria were determined. They are presented in Table 7.

TABLE VII. Global WeIGHTS OF CRITERIA

\begin{tabular}{|c|c|c|}
\hline Set of criteria & Criterion & Global weight \\
\hline \multirow{4}{*}{ K1 } & $\mathrm{K} 11$ & 0,063 \\
\cline { 2 - 3 } & $\mathrm{K} 12$ & 0,117 \\
\cline { 2 - 3 } & $\mathrm{K} 13$ & 0,117 \\
\cline { 2 - 3 } & $\mathrm{K} 14$ & 0,036 \\
\hline \multirow{3}{*}{ K2 } & $\mathrm{K} 21$ & 0,107 \\
\cline { 2 - 3 } & $\mathrm{K} 22$ & 0,041 \\
\hline \multirow{3}{*}{ K3 } & $\mathrm{K} 23$ & 0,186 \\
\cline { 2 - 3 } & $\mathrm{K} 31$ & 0,099 \\
\cline { 2 - 3 } & $\mathrm{K} 32$ & 0,180 \\
\hline
\end{tabular}

For ranking decision variants, the multi-criteria decision support Promethee II method was selected. It uses the outranking relation to the decision to choose the best alternative. This method uses the positive and negative flows of preferences specifying how much one alternative is greater than the other, and how much it is surpassed by other variants. Promethee II solves the sorting problem, and delivers the ranking of variants and indicate the best of them (in terms of Pareto evaluation). Using the Promethee II method, a decision maker can choose between six preference functions: simple criterion, the quasi criterion, the criterion with linear preference and preference level to the level of equivalence and preferences, the criterion with linear preference and indifference area, Gaussian criterion [23]. 
Preference functions based on the Promethee II method are shown in Figure 2.

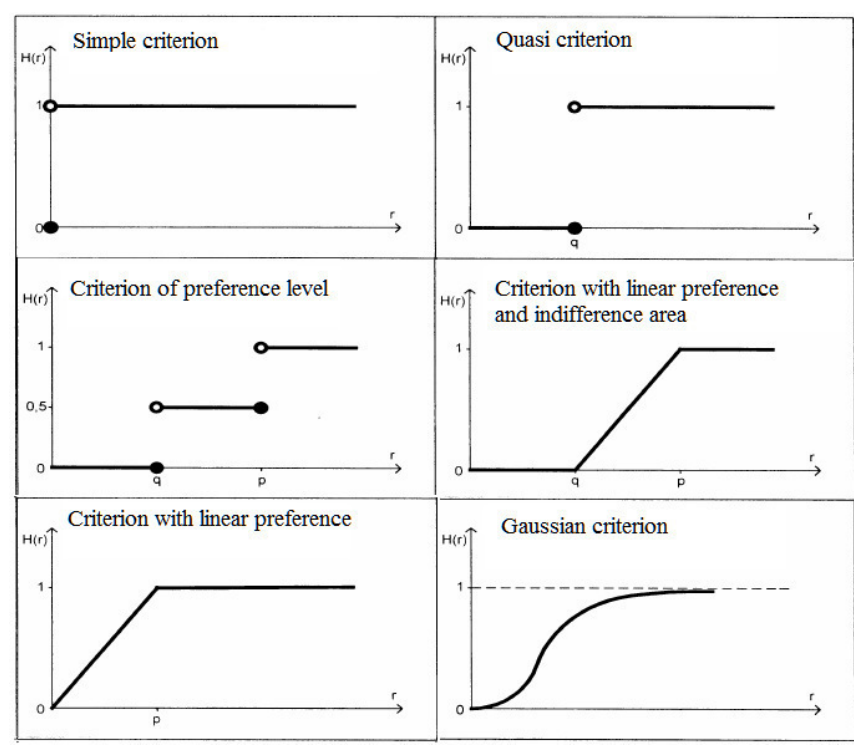

Fig 2. Preference functions used in the Promethee II method

Rankings of alternatives were determined using ordinary criterion as a function of preferences. The results of evaluating the options and their positions in the ranking are presented in Table 8 and Figure 3. In line with the weights of criteria as the best option, the location of W1 was selected. When analyzing Fig. 3, the various variants of the specific form of solutions due to the applied criteria and their weights should be noted. Two solutions are ranked as the best (W1 and W2), two as good (W4 and W6) and two as bad (W5 and W3).

The presented ranking of decision variants is not final. The subjective nature of the vector of introduced priorities and the need to examine the strength of fixation in the ranking of the different alternatives provide a basis for decision-making executed in the next stage sequentially involving the analysis of sensitivity of this decision-making model.
TABle VIII. PREFERENCE Flows IN ALTERnATIVES AND THEIR POSITION IN THE FINAL RANKING

\begin{tabular}{|c|c|c|c|c|}
\hline $\begin{array}{c}\text { Decision } \\
\text { variant }\end{array}$ & $\begin{array}{c}\text { Preference } \\
\text { flow } \boldsymbol{\Phi +}\end{array}$ & $\begin{array}{c}\text { Preference } \\
\text { flow } \boldsymbol{\Phi - ~}\end{array}$ & $\begin{array}{c}\text { Preference } \\
\text { flow } \boldsymbol{\Phi} \text { netto }\end{array}$ & Ranking \\
\hline W1 & 0,5967 & 0,36 & 0,2367 & 1 \\
\hline W2 & 0,5724 & 0,3645 & 0,2079 & 2 \\
\hline W3 & 0,2906 & 0,6517 & $-0,3611$ & 6 \\
\hline W4 & 0,5297 & 0,4125 & 0,1172 & 3 \\
\hline W5 & 0,3362 & 0,6007 & $-0,2645$ & 5 \\
\hline W6 & 0,4994 & 0,4356 & 0,0638 & 4 \\
\hline
\end{tabular}

\section{Sensitivity analysis of the Resulting solution to the PROBLEM OF CHOOSING A WIND FARM LOCATION}

The Promethee II method also enables a broad analysis of theresults, including a sensitivity analysis, and also provides an analytical tool, GAIA (ang. Geometrical Analysis for Interactive Assistance). GAIA aims to provide a complete graphical representation of the decision problem, so it allows the analysis of "goodness"-obtained solutions and provides directions for its possible improvement. The GAIA methodology information concerning the k-criteria of the decision problem in the $\mathrm{k}$-dimensional space that is projected onto a sphere, so that a part of the information is lost, is presented, among others, including the $Л$ vector, indicating the weights assigned to each criterion [24]. Alternatives are represented by points and criteria preferences are symbolized by vectors. If these vectors are oriented in the same direction, this means that they are not represented by the criteria in a similar way and it affects the global assessment of variants. The length of the vector indicates the strength of a given criterion to assess the global options. The closer a vector is to the end of a particular alternative, the more the vector supports this alternative, resulting in its ranking [23]. Examination of the results was conducted through a GAIA analysis representing individual criteria, which is shown in Figure 4.

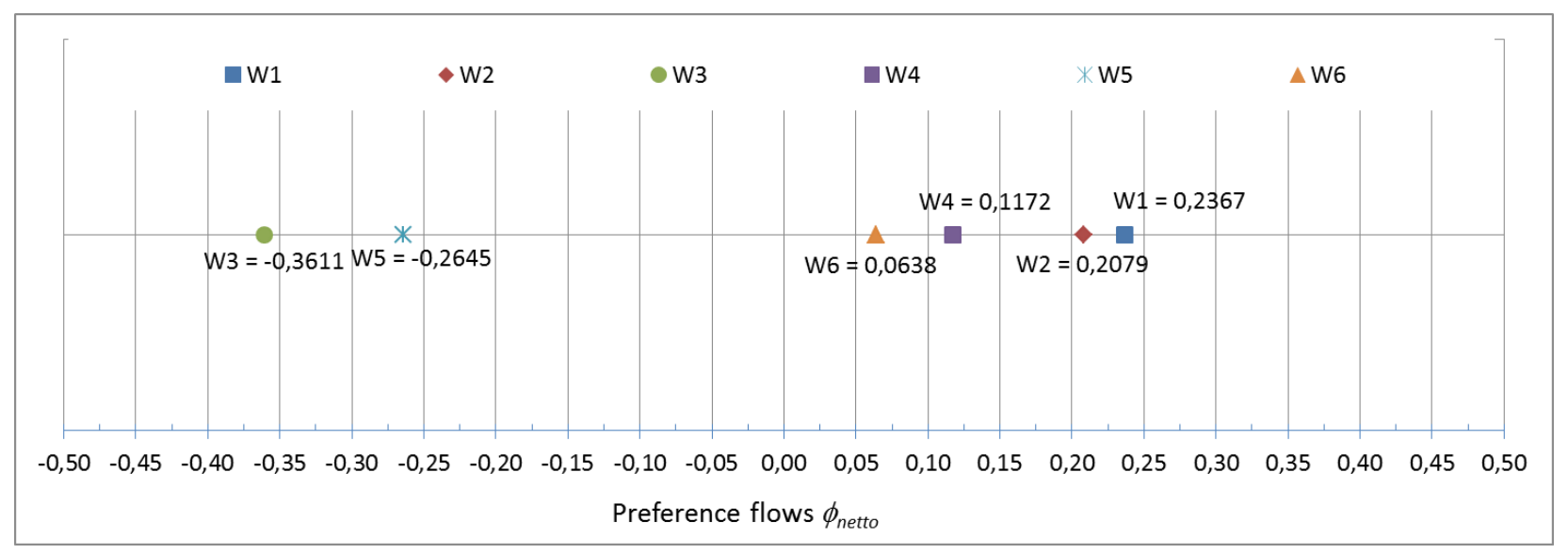

Fig 3. Netto preference flows in variants 


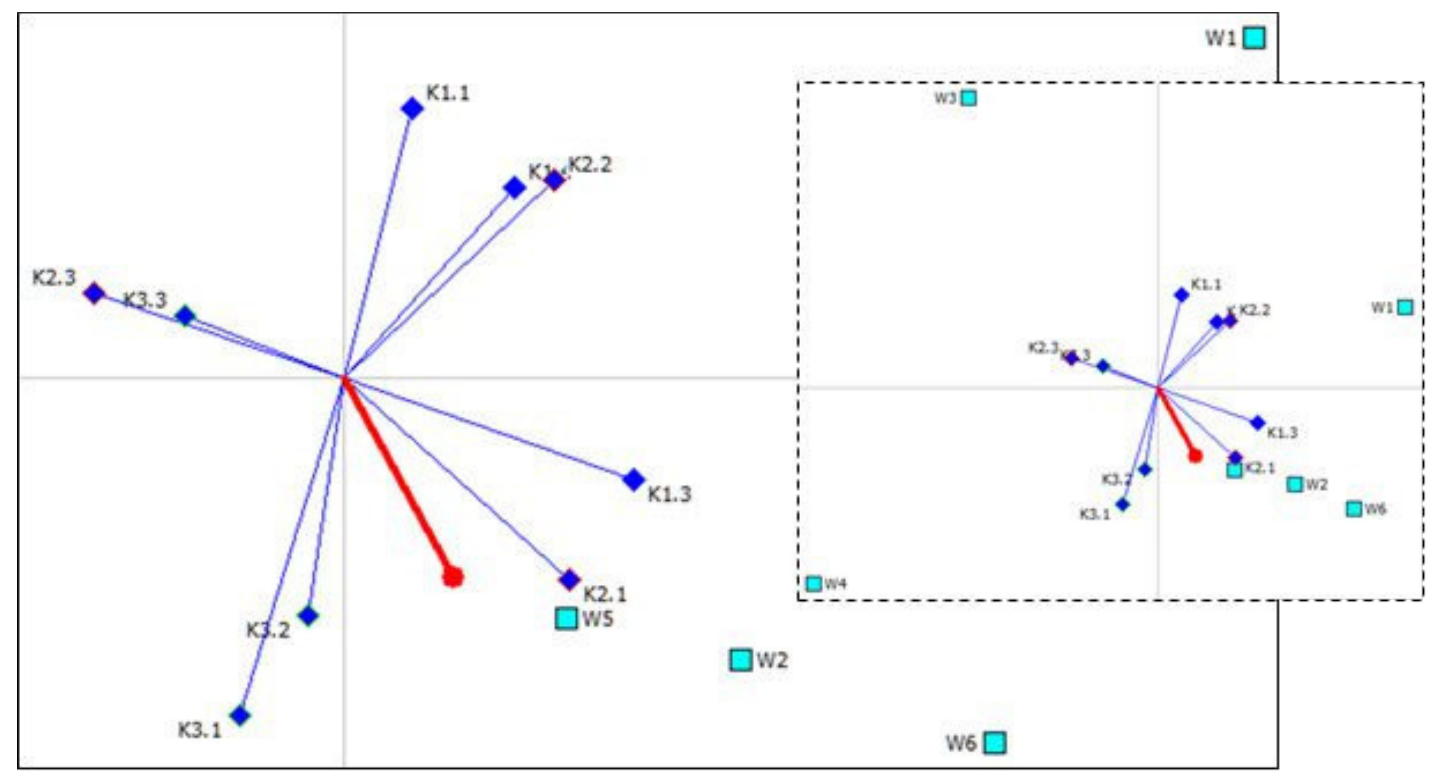

Fig 4. GAIA sphere representing individual criteria

When analyzing Fig. 4, it can be concluded that all the criteria have a similar effect on the acquired global assessment of variations, since the lengths of their vectors are all similar. However, there is a slight difference between the lengths of the $\mathrm{K} 31$ and $\mathrm{K} 32$ vectors, resulting from the difference of the weights given to these criteria. Shown here are the criteria coalitions and conflicts. For example, the criteria for $\mathrm{K} 31$ and $\mathrm{K} 32$ are compatible in the sense that, for most embodiments, a high value of $\mathrm{K} 31$ is associated with a high value of K32. However, these criteria are in conflict with K11; for variants with a high level of K31 and K32, the value of K11 is usually low. K14 and K22 support variant $\mathrm{W} 1$ because they are turned in his direction, and K13 and K21 criteria support the variants W1, W2, W5, W6, undermining the global assessment of the W3 and W4 variants. Due to the fact that the analysis of a multi-criteria decision problem using the GAIA strategy is projected onto a sphere, some information is lost. An example could be a vector compromise that seems to aim towards W5, while the highest rating is given to variants $\mathrm{W} 1$ and $\mathrm{W} 2$. The study also obtained solutions through the analysis of the GAIA sphere, which represented the sets of criteria. This sphere is shown in Figure 5.

Seeing The GAIA sphere from the perspective of criteria sets, it can be seen that the criteria related to spatial factors support the W1, W2 and W6 variants the most, since the end of the vector representing this collection lies closest to the specified options. The socio-environmental criteria strengthen the position of variants W2 and W4. The strength of the impact of these two sets of criteria for the solution of the decision problem is similar and is much larger than the impact of economic factors. Compromise vector reveals that variants of $\mathrm{W} 1, \mathrm{~W} 2, \mathrm{~W} 4$ and W6 are a much better choice than W3 and W5 variants. It should also be noted that the various sets criteria are not opposed to each other, and to some extent, the economic criteria are consistent with the environmental and social criteria.

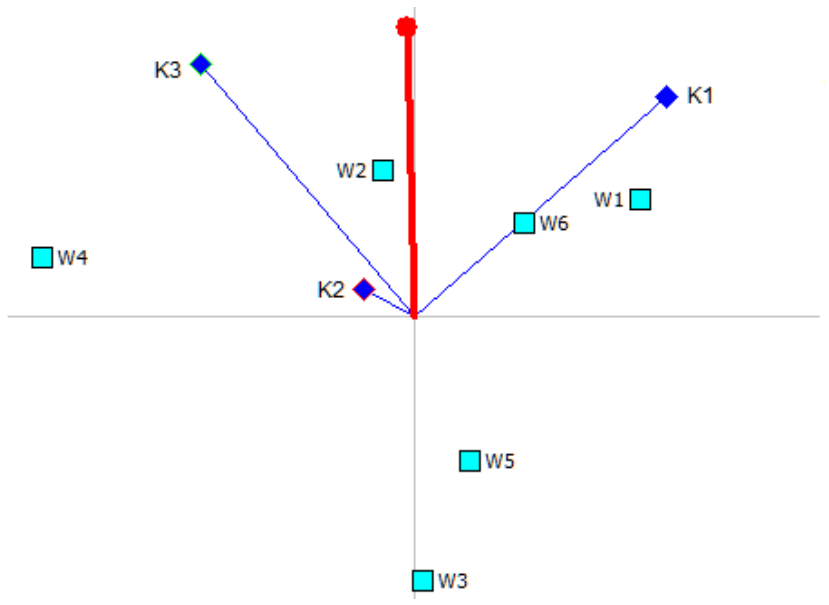

Fig 5. The GAIA sphere sets of criteria

The next step in the study was the analysis of the results to determine the stability of the sensitivity of the solution obtained, in terms of changing the weights of criteria. Due to the fact that, when looking at the problem from different perspectives (economic, localization, social and environmental), the relevance of the different sets of criteria may be seen as different, the weight of the sets of criteria was considered in this analysis. The results of the sensitivity analysis were included in Figure 6.

A sensitivity analysis shows that the solution is resistant to changes in sets of criteria weights in the range of $3 \%$. If the environmental and social risks were much more important than other factors (weight K2>45\%), or if the weight of the economic factors was more than $75 \%$, then the best option would be the W4 variant of the decision problem. The 

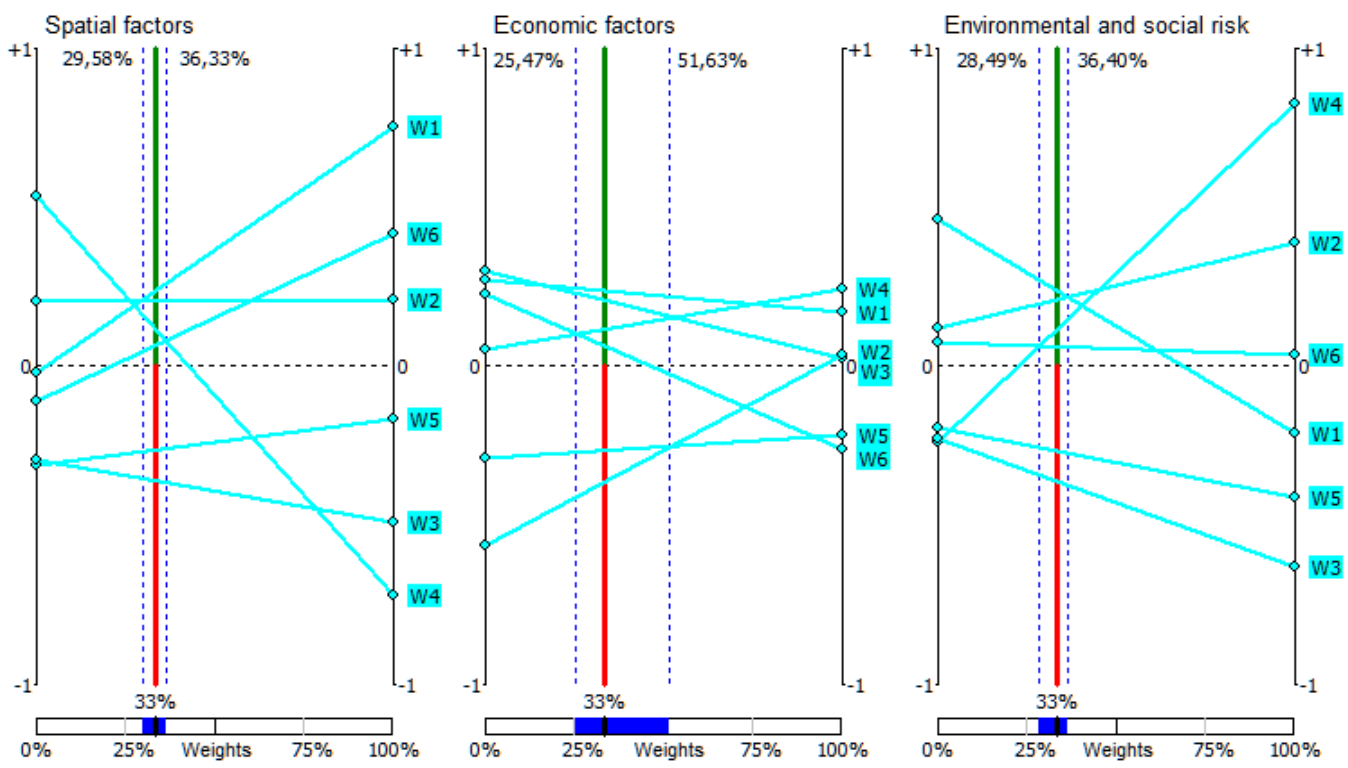

Fig 6. Sensitivity analysis of obtained solutions and weights

weight of a small range of socio-economic risks $(36.4 \%$ $45 \%$ ), means that the best solution is also becoming a variant W2.

As part of the verification of the results the problem of ranking variants was determined by using a linear preference function instead of the true criterion. In this case, as a preference threshold for each of the criteria the standard deviation of variants with respect to a given criterion was computed. The netto preference flows and the rankings obtained in this study are included in Table 9.

Using the linear preference, there only one change of position of the resulting ranking; an exchange of the positions of the W4 and W6 variants was observed. As for the Pareto optimal solution, variant $\mathrm{W} 1$, using the linear preference, still received a higher than previously aggregated overall rank. The results of the sensitivity analysis for the solution obtained by using a linear preference function is shown in Figure 7. It shows the ranking of higher stability generated by applying the criterion with linear preference, as compared to the ranking obtained using the true criterion. Option W1 is the best at any weight and increase collections of spatial and economic criteria. For a group of socioenvironmental criteria it remains in the first position in the ranking and increasing the importance of this group of up to nearly $12 \%$. It can be concluded that the variant of the wind farm location $\mathrm{W} 1$ is a rational solution to the decision problem.
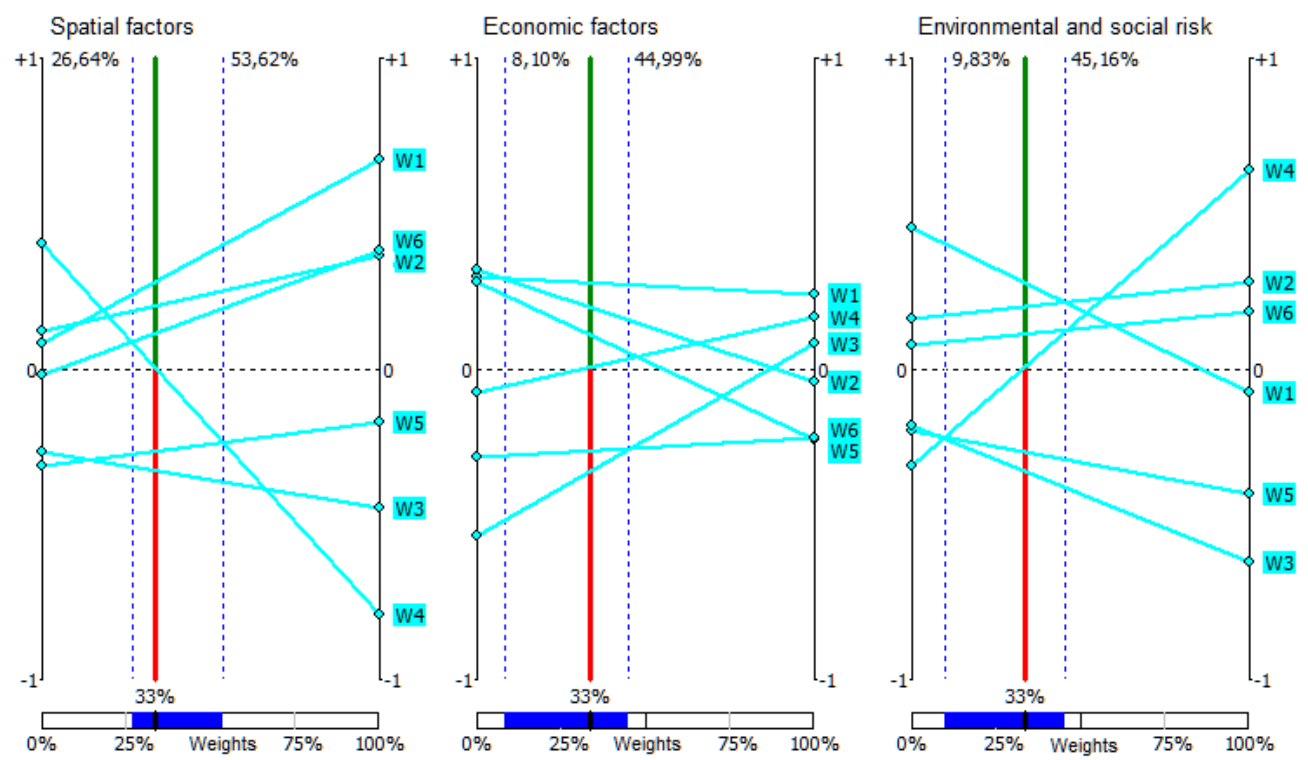

Fig 7. Sensitivity analysis of solutions obtained using the linear preference function 
Table IX. Preference Flows in ALternatives AND THEIR POSITION IN THE RANKINGS

\begin{tabular}{|c|c|c|c|c|}
\hline \multirow{2}{*}{$\begin{array}{c}\begin{array}{c}\text { Preference } \\
\text { criterion }\end{array} \\
\begin{array}{c}\text { Decision } \\
\text { variant }\end{array}\end{array}$} & \multicolumn{2}{|c|}{ Simple criterion } & \multicolumn{2}{|c|}{$\begin{array}{c}\text { Criterion with linear } \\
\text { preference }\end{array}$} \\
\hline & $\begin{array}{c}\text { Preference } \\
\text { flow } \Phi \text { netto }\end{array}$ & Ranking & $\begin{array}{c}\text { Preference } \\
\text { flow } \Phi \text { netto }\end{array}$ & Ranking \\
\hline W1 & 0,2367 & 1 & 0,2773 & 1 \\
\hline W2 & 0,2079 & 2 & 0,2001 & 2 \\
\hline W3 & $-0,3611$ & 6 & $-0,33$ & 6 \\
\hline W4 & 0,1172 & 3 & 0,0056 & 4 \\
\hline W5 & $-0,2645$ & 5 & $-0,2649$ & 5 \\
\hline W6 & 0,0638 & 4 & 0,1121 & 3 \\
\hline
\end{tabular}

\section{Summary}

Design of Support system for selection of the location of renewable energy sources requires proper analytical methods. A practical application of multi-criteria decision support methods, as a maethodological basement for this system such as AHP and Promethee II was presented in this paper. It was verified for assessment of the potential location for offshore wind farm in Polish maritime areas. The possibility of linking these methods was presented and an advantage of the proposed approach was demonstrated. The pairwise comparisons, associated mainly with AHP, were used for the priorities to determine the vector which was used during the usage of Promethee II calculation method. The Promethee II method allowed for a comprehensive analysis of the resulting solution of the decision problem by using the GAIA sphere and sensitivity analysis. In addition, the solution obtained using the real criteria was confirmed by using a linear preference function. It should be noted that there were some limitations of the analysis conducted. Data representation is restricted to the field of crisp numbers, but each of the presented methods allows the use of fuzzy logic rules. In the future work it is assumed to extend the discussion about the use of an assessment methods based on, for example, the impact matrix implemented within the NAIADE method.

\section{REFERENCES}

[1] M. Kaltschmitt, W. Streicher, A. Wiese, "Renewable Energy: Technology, Economics and Environment,"Springer Science \& Business Media, 03.06.2007 - 596, http://dx.doi.org/10.1007/3-54070949-5

[2] E. Eleftheriadou, D. Haralambopoulos, H. Polatidis, "A Multi-Criteria Approach to Siting Wind Farms in Lesvos, Greece," http://www.srcosmos.gr

[3] R. Gasch and J. Twele (Eds.), "Wind Power Plants: Fundamentals, Design, Construction and Operation", Springer, Berlin, Heidelberg 2012, http://dx.doi.org/10.1007/978-3-642-22938-1

[4] International Renewable Energy Agency (IRENA), www.irena.org

[5] http://www.transport.gov.pl/2-4e393a7f7308f.htm

[6] http://morskiefarmywiatrowe.pl/strefa-wiedzy/polska
[7] Z. Lubośny, "Wind Turbine Operation in Electric Power Systems. Advanced Modeling", Springer-Verlag, Berlin Heidelberg New York, 2003.

[8] J. Wątróbski, J. Jankowski, Z. Piotrowski, "The Selection of Multicriteria Method Based on Unstructured Decision Problem Description," Lecture Notes in Artificial Intelligence, vol. 8733, pp. 454-465, 2014, http://dx.doi.org/10.1007/978-3-319-11289-3 46

[9] R. Pesta, "Analiza opłacalności budowy farmy wiatrowej o mocy 40MW," Rynek Energii, nr http://www.cire.pl/pliki/2/analizabudowyfarmy.pdf

[10] http://maps.helcom.fi

[11] http://www.ine-isd.org.pl

[12] L.J. Kaszubowski, R. Coufal, "Wstępny podział geologicznoinżynierski dna polskiej części Morza Bałtyckiego," Inżynieria Morska i Geotechnika, nr 3, 2010

[13] P. Ziemba, M. Piwowarski, J. Jankowski, J. Watróbski, "Method of Criteria Selection and Weights Calculation in the Process of Web Projects Evaluation," Lecture Notes in Artificial Intelligence, vol. 8733, pp. 684-693, 2014, http://dx.doi.org/10.1007/978-3-31911289-3 69

[14] J. Burton, K. Hubacek, "Is small beautiful? A multicriteria assessment of small-scale energy technology applications in local governments," Energy Policy, vol. 35, pp. 6402-6412, 2007 http://dx.doi.org/10.1016/j.enpol.2007.08.002

[15] F. Cavallaro, L. Ciraolo, "A multicriteria approach to evaluate wind energy plants on an Italian Island," Energy Policy, vol. 33, pp. 235244, 2005.

[16] F. Forte, P. Nijkamp, F. Torrieri, "Shared Choices on Local Sustainability Projects: A Decision Support Framework,", 2001, ftp://zappa.ubvu.vu.nl/20010024.pdf

[17] G. Gamboa, G. Munda, "The problem of windfarm location: A social multi-criteria evaluation framework," Energy Policy, vol. 35, pp. 1564-1583, 2007, http://dx.doi.org/10.1016/j.enpol.2006.04.021

[18] E. Georgopoulou, D. Lalas, L. Papagiannakis, "A Multicriteria Decision Aid approach for energy planning problems: The case of renewable energy option," European Journal of Operational Research, vol. 103 , pp. 38-54, 1997.

[19] A.H.I. Lee, H.H. Chen, H. Kang, "Multi-criteria decision making on strategic selection of wind farms," Renewable Energy, vol. 34, pp. 120-126, 2009, http://dx.doi.org/10.1016/j.renene.2008.04.013

[20] K. Nigim, N. Munier, J. Green, "Pre-feasibility MCDM tools to aid communities in prioritizing local diable renewable energy sources," Renewable Energy, vol. 29, pp. 1775-1791, 2004.

[21] T.L. Saaty, "How to make a decision: The Analytic Hierarchy Process," European Journal of Operational Research, vol. 48, pp. 926, 1990.

[22] T.L. Saaty, "Why the Magic Number Seven Plus or Minus Two," Mathematical and Computer Modelling, vol. 38, pp. 233-244, 2003.

[23] J.P. Brans, B. Mareschal, "Promethee Methods," in Multiple Criteria Decision Analysis, J. Figueira, S. Greco, M. Ehrgott, Ed. Boston: Springer, 2005, pp. 163-195.

[24] G. Janssens, M. Pangilinan, "Multiple Criteria Performance Analysis of Non-dominated Sets Obtained by Multi-objective Evolutionary Algorithms for Optimisation," Artificial Intelligence Applications and Innovations, vol. 339, pp. 94-103, 2010 http://dx.doi.org/10.1007/978-3-642-16239-8_15

[25] T. Kaya, C. Kahraman, "Multicriteria renewable energy planning using an integrated fuzzy VIKOR \& AHP methodology: The case of Istanbul," Energy, vol. 35, pp. 2517-2527, 2010, http://dx.doi.org/10.1016/j.energy.2010.02.051

[26] M. Baysal, A. Sarucan, C. Kahraman, O. Engin, "The selection of renewable energy power plant technology using fuzzy data envelopment analysis," in Proc. the World Congress on Engineering, vol. II, London, July 2011,.

[27] Y. Topcu, F. Ulengin, "Energy for the future: An integrated decision aid for the case of Turkey," Energy, vol. 29, pp. 137-154, 2004.

[28] P. Haurant, P. Oberti, M. Muselli, "Multicriteria selection aiding related to photovoltaic plants on farming fields on Corsica island: A real case study using the ELECTRE outranking framework," Energy Policy, vol. 39, no. 2, pp. 676-688, 2011, http://dx.doi.org/10.1016/j.enpol.2010.10.040 
[29] S. Al-Yahyaia, Y. Charabi, A. Gastli, A. Al-Badi, "Wind farm land suitability indexing using multi-criteria analysis," Renewable Energy, vol. $44, \quad$ pp. $80-87$, http://dx.doi.org/10.1016/j.renene.2012.01.004
[30] N. Afgan, M. Carvalho, "Multi-criteria assessment of new and renewable energy power plants," Energy, vol. 27, pp. 739-755, 2002

[31] A. Sagbas, A. Mazmanoglu, "Use of multicriteria decision analysis to assess alternative wind power plants," Journal of Engg. Research, vol. 2, no. 1, pp. 147-161, 2014. 